\title{
Is Physical Activity Level in Physical Education Lesson Related to Fundamental Movement Skills at Elementary Schools?
}

\author{
Ricky Wibowo*, Didin Budiman, Gano Sumarno, Mesa Rahmi Stephani, Wulandari Putri \\ Faculty of Sport and Health Education, Universitas Pendidikan Indonesia, Bandung, Indonesia
}

Received April 25, 2021; Revised June 16, 2021; Accepted July 18, 2021

\section{Cite This Paper in the following Citation Styles}

(a): [1] Ricky Wibowo, Didin Budiman, Gano Sumarno, Mesa Rahmi Stephani, Wulandari Putri, "Is Physical Activity Level in Physical Education Lesson Related to Fundamental Movement Skills at Elementary Schools?," International Journal of Human Movement and Sports Sciences, Vol. 9, No. 4A, pp. 31 - 37, 2021. DOI: 10.13189/saj.2021.091306.

(b): Ricky Wibowo, Didin Budiman, Gano Sumarno, Mesa Rahmi Stephani, Wulandari Putri (2021). Is Physical Activity Level in Physical Education Lesson Related to Fundamental Movement Skills at Elementary Schools?. International Journal of Human Movement and Sports Sciences, 9(4A), 31 - 37. DOI: 10.13189/saj.2021.091306.

Copyright $\bigcirc 2021$ by authors, all rights reserved. Authors agree that this article remains permanently open access under the terms of the Creative Commons Attribution License 4.0 International License

\begin{abstract}
Objectives: The results of the study in various countries show that students do not achieve the recommended level of physical activity during physical education class. The purpose of this study was to investigate the level of physical activity of elementary school students in a physical education class and the relation between the level of physical activity of elementary school students and fundamental movement skills (FMS). Methods: Correlational approach was used to analyze the results of this study. Third grade elementary school students $(n=43$; boys $=23$; girl $=20)$ were enrolled in this study. The instrument used to measure the level of physical activity was the heart rate monitor chest strap (Polar H10) connected to IPAD Polar Team application Mini that was used during physical education class. To measure FMS, TGMD-2 was used consisting of locomotor and object control skills. Results: The results indicated that the distribution of physical activity levels in Physical Education learning at elementary school classes in Indonesia did not reach the recommended level of physical activity (31.20\%) MVPA. Boys only reached 32,65\% MVPA on average and only $10 \%$ of them managed to reach the recommended MVPA. Meanwhile, the girls reached $31,08 \%$ MVPA and only $16 \%$ of them reached the recommended MVPA. FMS was correlated with the level of physical activity of students during Physical Education learning at the low level (.203). Conclusions: Physical education class needs to pay attention to the intensity of
\end{abstract}

children's physical activities to get benefit from physical activities besides learning through movement.

Keywords Fundamental Movement Skills, Physical Activity Level, Physical Education Lesson

\section{Introduction}

In Indonesia, according to the data of the Basic Health Research, obesity prevalence in people aged $\geq 18$ years has been increasing for the last five years. In 2003, the obesity case reached $10.5 \%$, while in 2013 it became $14.8 \%$, increased $4.3 \%$. However, the case of obesity in 2018 escalated to $21.8 \%$, increased $7 \%$ since 2013 . By calculating the annual case from 2013-2018, the obesity case increased by $1.4 \%$ every year. It requires a concern from the educators, especially from Physical Education teachers who have a strategic role in promoting health. It is relevant to the Ministry of Health of Indonesia regarding physical activity at school or after school. The recommended physical activity at school includes 30 minutes physical activity/exercise/healthy gymnastics before the teaching learning process begins every day and the optimization of break time by doing skipping, etc. Meanwhile, it is recommended that physical activity after school is conducted by doing moderate to vigorous 
physical activity for at least 60 minutes (accumulative) per day [1].

The main role of Physical Education is to give education of movement and through movement, including opportunity to develop the affective and psychomotor domain. However, it is essential to be understood that Physical Education has a potential to increase student participation that could have an impact on their long life health and learning [2]. Physical activity is one of important aspects from various programs for maintaining and increasing health degree. The inadequate physical activity is the main factor of various diseases.

Physical Education at school is believed as a strategic media to promote physical activity for children and teenagers. Quality physical education has important contributions to health [3]. Children at elementary school usually have an active characteristic, but they frequently do not receive recommended physical activity level during learning. The habituation of regular physical activity is the key stage of active life style in the adulthood period [4]. The regular physical activity could decrease the risk of cardiovascular and metabolic diseases in adulthood $[5,6]$. According to the result of the review, it recommends that school aged children should participate in physical activity five times a week for 60 minutes for each activity [7]. The suggested intensity is $40-59 \%$ heart rate reserve (HRR), known as Moderate to Vigorous Physical Activity (MVPA).

The concern of Physical Education teachers on the time spent by the students during Physical Education class with vigorous intensity requires a serious attention [8]. According to the report of previous research, the students got only 10 to $15 \%$ or only five minutes physical activity in vigorous intensity during the Physical Education class $[9,10]$. It is irrelevant to the theory of fitness development that it requires $60 \%$ of maximum heart rate reserve for 20 minutes conducted three times a week [11].

In relation with the physical activity level or intensity during Physical Education learning process, it is recommended to do at least $50 \%$ activity with MVPA intensity as the effort to increase cardiovascular fitness [5,12-16]. Other research suggested that 20 minutes of MVPA intensity or $50 \%$ of the handball learning is reachable and has a positive contribution on fitness [17]. The literature concluded that the Physical Education teachers should pay a serious attention in providing a suitable and accurate material required by the children related to their developmental stage.

To find out the physical activity level of the children during learning, heart rate monitor is a tool that is commonly used by researchers and has been tested for its validity and reliability [18][19]. Heart rate monitor is also suitable for evaluating MVPA [5]. According to the previous study, some studies are strongly relevant. It reported that the average of MVPA intensity is only $21.62 \pm 14.33 \%$ from the total of learning [20]. Meanwhile, the result of another research shows that the Physical Education conducted has MVPA intensity more than 50\% of the total of Physical Education learning $[14,15,18,19,22]$.

Based on review of previous studies, it is urgent that physical activity during Physical Education learning process is investigated, especially for the elementary school level. By investigating the MVPA intensity, it is expected that the recommendation can be given to the teacher of Physical Education in arranging the lesson plan that is appropriate and needed by the students. The Physical Education learning is highly related with learning through movement. The learning activity is agreed to provide physical activity experience, playing, and exercising for the students that are planned systematically to stimulate their growth and development of physical aspect, motor skills, thinking skill, emotion, social and moral aspects [23]. The growth and development of children's physical aspect should receive a serious concern from the Physical Education teachers. The elementary school students require various physical activity experiences that have a recommended intensity of the experts. The appropriate physical activity experiences would give impacts on students' physical and psychological aspects. The students who are physically skilled are proven to have a better physical activity when they grow. The Physical Education learning at elementary schools is believed to be able to conduct the accurate movement intensity during the learning process. By knowing the movement intensity conducted during Physical Education class, the teachers are expected to arrange required physical activity needed by the children to develop their motor skill and physical development in elementary school.

Furthermore, the authors need to investigate the relationship between the physical activity levels administered by the students during Physical Education learning process with the fundamental movement skills. The fundamental movement skill is seen as a foundation of long-life physical activity [24]. A previous study also indicates that there is a positive relationship between basic movement skills with the regular participation of the children in physical activity [25]. The study showed that mastering fundamental movement skill in elementary level tends to increase the habit of doing physical activity and participating in regular physical activity, thus it is believed that it can prevent the obesity of the children [26,27]. Therefore, it rejects the misunderstanding statement that the fundamental movement skill of the children will occur naturally as they grow older $[26,27]$. For that reason, the children need to have a wide opportunity to do physical activity in order to develop their fundamental movement skills. In other words, the movement skill education should have been given and practiced from the elementary level.

From the previous study conducted by the authors, relationship between movement skill and children game performance in the context of simple manipulative learning 
material is proven to be crucial. The research concluded that the better the fundamental skills, the better the manipulative movement skills [28]. It also occurred in the locomotor movement and children involvement during the simple manipulative game learning. Regarding the gender of the students, the 9-year-old male students had a better game performance than female students. This research highlights that it is important to continue the study to find out the relationship between the fundamental movement skill and the level of the children activity level in Physical Education learning process. Therefore, the variable of the fundamental movement skills could describe another aspect of intensity performed by the students during the Physical Education learning.

According to the discussion above, the purpose of this study was to investigate the MVPA intensity during Physical Education lesson. Moreover, the author also aims to investigate the correlation of fundamental movement skills and physical activity level during Physical Education lesson.

\section{Methods}

\section{Participants}

This study was conducted in an elementary school in Indonesia. The school had an A national accreditation. Moreover, the school was chosen as the school which had characteristics required that represent the school in Indonesia with excellent accreditation. The sufficient facilities and the excellent quality of the students and teachers became the consideration of the researchers. The samples of the research were 43 third graders ( 23 boys \& 20 girls) aged 8-9 years. Before involving in the research, the researchers had received consent from their parents. The anthropometric measurement was conducted together with the Physical Education teachers a day before the data collection was conducted. The height was measured by using the stature meter, while the weight was measured by Seca 786. The result of observation showed that the students were healthy and did not have a physical disability. In addition, the detailed characteristics of the sample are presented in Table 1. This research also involved three Physical Education teachers that owned more than five year experience and had a Physical Education degree. The samples, during the research, was conducted, were physically healthy. The data collection was conducted outdoor in a 30x 45 meter.

Table 1. Anthropometric Characteristics of Male and Female Samples

\begin{tabular}{|c|c|c|c|c|}
\hline & \multicolumn{2}{|c|}{ Male $(\mathrm{n}=23)$} & \multicolumn{2}{c|}{ Female $(\mathrm{n}=20)$} \\
\hline & M & SD & M & SD \\
\hline Age (Years) & 8,31 & 0,44 & 8,34 & 0,62 \\
\hline Height $(\mathrm{m})$ & 1,29 & 0,04 & 1,3 & 0,06 \\
\hline Weight $(\mathrm{Kg})$ & 30,13 & 8,6 & 33,21 & 8,96 \\
\hline BMI & 17,9 & 4,5 & 19,45 & 4,41 \\
\hline
\end{tabular}

\section{Instrument and material}

The instrument of the research is the tool or the test used to collect the data. There were two instruments used to collect the data in this research, including Polar to investigate the MVPA intensity, and the TGMD-2 test to find out the fundamental movement skills. To monitor the physical activity level during Physical Education learning, the heart rate monitor was used. Previous research had used heart rate monitor to measure the level of physical activity in the Physical Education learning process and sports activities [12-14]. In this research, to measure the physical activity level in the pulse rate during the Physical Education learning process, the Polar $\mathrm{H} 10$ heart rate sensor connected to IPAD was used. The polar was installed at the chest by using a strap that is easy to wear and comfortable for the students. The installation of the polar was helped by the technician and laboratory assistant of The Faculty of Sport and Health Education, while the girls were helped by the female Physical Education teachers of the school. The Polar H10 was worn a moment before the Physical Education learning was conducted, then it was connected to the IPAD 3 in which the Polar Team application had been installed. The measurement was stopped when the teacher finished giving the learning material. The IPAD 3 recorded the data of the average heart rate, max heart rate, vigorous heart rate, and non-vigorous heart rate.

The content of the learning material when the data were collected was a locomotor physical education lesson. The content of the learning material was suitable with the curriculum at the school without the intervention of the researcher. Meanwhile, the duration of learning was 40 minutes that belonged to the core learning without the opening and the closing. 


\section{Data collection and analysis}

The first test collected was The Test of Gross Motor Development (TGMD-2). This test which aims to measure the fundamental movement skills of children in the age range of 3-10 years consists of 6 locomotor skills tests and 6 object control skills tests. Data were retrieved according to test guidelines from [29] and previous studies [28,30]. First, the participants do the locomotor test and then the object control test. Each test item is placed lengthwise and parallel. Participants took part in a series of tests and were given the opportunity twice, where scores of both trials were then summed up to obtain a raw score. The raw scores of the locomotor and object-control skills were added to provide an overall score which was then converted to a percentile score, standardized for age and sex. The construct validity of the TGMD-2 test for component locomotors is $r=.68-78$ and for manipulative components $\mathrm{r}=.66-.87$. The overall value of the Cronbach Alpha TGMD-2 test for each item test range is between .82 to .83 . Two days later, physical activity level data was taken. The data is taken during physical education lessons. The teaching and learning activities are carried out in the outdoor field. Before teaching and learning activities begin participants are given instructions to wear a heart rate monitor and use the tool. The children were asked not to remove the device until the research team removed the device again. The teacher is asked to teach as usual in accordance with the learning implementation plan that has been prepared by the teacher.

The data were collected using the Polar Team application during the learning process. The data were then calculated, analyzed, and presented into light, vigorous, moderate, and MVPA (vigorous + moderate) category and the percentage of the active learning time. Meanwhile, to decide the limit of moderate and vigorous-intensity (Heart rate cut-points), the Stratton norm was used. The norm is the prediction of the minimum and maximum pulse rate based on age [17]. The fundamental movement skill was analyzed by using TGMD-2. The result of the test was compared with the table that is suitable for the age of the subject of the research. Each variable was then processed using SPSS 18. The initial analysis was the normality test by using the Kolmogorov-Smirnov test and homogeneity test by using Levene's test. To find out the relationship between the level of physical activity and fundamental movement skills, Pearson's correlation coefficients (for parametric data) and Spearman's correlation coefficients (for non-parametric data) were used.
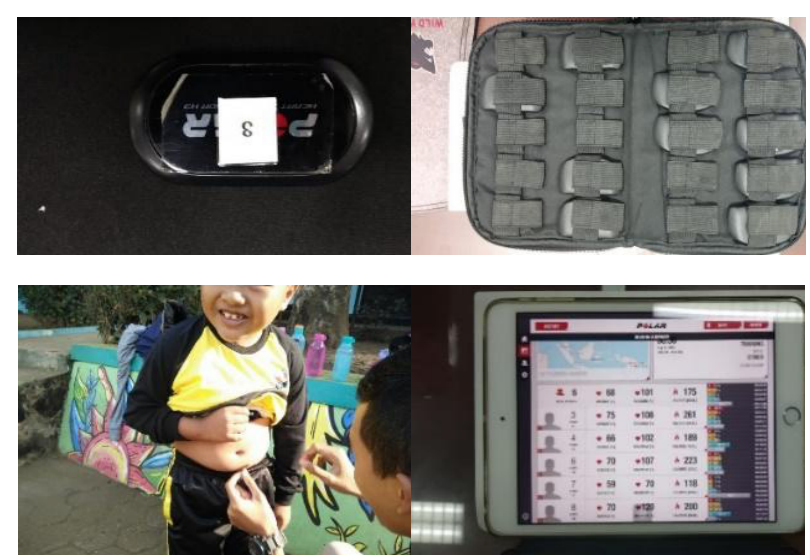

Figure 1. Heart Rate Monitor Chest Strap (Polar H10)

\section{Results}

The Physical Education material when the data were collected was the locomotor activity, which was in line with the syllabus and learning plan used by the teachers. The focus of the research was to find out the physical activity level during the Physical Education learning process was conducted. Furthermore, we also presented the data on the relationship between the physical activity level and fundamental movement skill. The result of the physical activity measured by polar $\mathrm{H} 10$ is shown in table 2 .

Table 2 describes that boy's students only reached $32,65 \%$ MVPA on average and only $10 \%$ of the girl's students reached the recommended MVPA. Meanwhile, the girl's students reached $31,08 \%$ MVPA and only $16 \%$ of the girl's students reached the recommended MVPA. In addition, the duration of MVPA was 12.43 minutes for boy's and 12.52 minutes for girls from the total 40 minutes of active learning time. Meanwhile, the result of data collection of fundamental movement skill, measured by the TGMD-2 Test, is presented in Table 3. According to the data, boy's students gained an average FMS score of 15,82, while girl's students gained an average score of 17,17. In general, the FMS score of the elementary school students was 16,5 that is categorized as below average in fundamental movement skill.

Table 2. The mean of MVPA percentage and the percentage of students reaching 50\% MVPA during physical education learning process ( $n=43$ ).

\begin{tabular}{|c|c|c|c|c|c|}
\hline & Total & $\begin{array}{c}\text { Mean of MVPA } \\
\text { Percentage }\end{array}$ & $\begin{array}{c}\text { SD } \\
\text { MVPA } \\
\end{array}$ & $\begin{array}{c}\text { MVPA Time } \\
\text { (minutes) }\end{array}$ & $\begin{array}{c}\text { Percentage of Sample } \\
\text { Reaching 50\% }\end{array}$ \\
\hline \multicolumn{6}{|c|}{ Sex } \\
\hline Boys & 23 & 32,65 & 1,5 & 12,43 & 10 \\
\hline Girls & 20 & 31,08 & 2,2 & 12,52 & 16 \\
\hline Total & 43 & 31,20 & 1,8 & 12,48 & 13 \\
\hline
\end{tabular}


Table 3. Mean values for TGMD-2

\begin{tabular}{ccccc}
\hline Variable & $\begin{array}{c}\text { Boys } \\
(\mathbf{M e a n} \pm \mathbf{S D})\end{array}$ & $\begin{array}{c}\text { Girls } \\
(\text { Mean } \pm \text { SD) }\end{array}$ & Total & Category \\
\hline Locomotor & $9,18 \pm 2,21$ & $9 \pm 1,96$ & & \\
Object control & $6,64 \pm 2,60$ & $8,17 \pm 1,52$ & & Below average \\
FMS & $15,82 \pm 3,88$ & $17,17 \pm 2,11$ & $16,5 \pm 3,1$ & \\
\hline
\end{tabular}

Meanwhile, the correlation between the fundamental movement skill and the physical activity level during locomotor physical education lessons was found low as depicted in table 4. According to table 4, the correlation value is .203. It indicates that both variables had a relationship but in a low correlation.

Table 4. The correlation between physical activity level and fundamental movement skill

\begin{tabular}{|c|c|c|c|c|c|}
\hline & & MVPA & LOC & OC & SUM \\
\hline \multirow{3}{*}{ MVPA } & $\begin{array}{c}\text { Pearson } \\
\text { Correlation }\end{array}$ & 1 & .166 & .166 & .203 \\
\hline & $\begin{array}{c}\text { Sig. } \\
\text { (2-tailed) }\end{array}$ & & .450 & .450 & .353 \\
\hline & $\mathrm{N}$ & 43 & 43 & 43 & 43 \\
\hline \multirow{3}{*}{ LOC } & $\begin{array}{c}\text { Pearson } \\
\text { Correlation } \\
\end{array}$ & .166 & 1 & .326 & $.784^{* *}$ \\
\hline & $\begin{array}{c}\text { Sig. } \\
\text { (2-tailed) }\end{array}$ & .450 & & .129 & .000 \\
\hline & $\mathrm{N}$ & 43 & 43 & 43 & 43 \\
\hline \multirow{3}{*}{ OC } & $\begin{array}{c}\text { Pearson } \\
\text { Correlation } \\
\end{array}$ & .166 & .326 & 1 & $.843^{* *}$ \\
\hline & $\begin{array}{c}\text { Sig. } \\
\text { (2-tailed) }\end{array}$ & .450 & .129 & & .000 \\
\hline & $\mathrm{N}$ & 43 & 43 & 43 & 43 \\
\hline \multirow{3}{*}{ SUM } & $\begin{array}{c}\text { Pearson } \\
\text { Correlation }\end{array}$ & .203 & $.784^{* *}$ & $.843^{* *}$ & 1 \\
\hline & $\begin{array}{c}\text { Sig. } \\
\text { (2-tailed) }\end{array}$ & .353 & .000 & .000 & \\
\hline & $\mathrm{N}$ & 43 & 43 & 43 & 43 \\
\hline
\end{tabular}

\section{Discussion}

Based on the results of the study, data obtained from the heart rate monitor during the locomotor physical education lesson showed a lower percentage than the recommendations set by experts [31]. The results show a percentage of $31.20 \%$ of the time spent with MVPA intensity below $50 \%$ following the recommendations. When compared with previous studies, the results of this study showed a greater percentage $(28 \%)$ with learning activities of adventure physical education lessons [32]; however, it is lower than other studies ( $32 \%$ to $48 \%$ ) with traditional physical education lessons with observations using the SOFIT [33].

From the observations in the class when the teacher teaches, the low percentage of MVPA is caused by the lesson not require much energy. For example, when teaching running activities, the teacher gives instructions on approaches to techniques approach, starting with the movement of the arm, leg, and body position in a static position. In addition, the teacher also teaches the coordination of children's movements by making a line of queues so that students have a long time to wait their turn. The preparation of tools and teacher demonstrations also contribute to the low intensity of student movement. During the tag games session, it was seen that students were less enthusiastic in participating in the learning.

Based on these observations, it seems necessary for physical education teachers in elementary schools to prepare locomotor teaching materials that can make students move with moderate to high intensity and without having to wait in a queue. In addition, the teacher should provide feedback to students when students succeed in conducting movement instructions and when students look less enthusiastic in learning the teacher have to immediately provide feedback, thus students are always motivated to engage in learning. However, the teacher should provide feedback quickly and efficiently. Giving feedback is believed to increase the level of physical activity of children when learning [14]. In addition, preparing the equipment before starting learning is necessary. By preparing all the tools used before learning can reduce the time students wait.

When compared between boys and girls, girls look better than boys but are not much different and almost the same. Several factors affect these results; among others are the different levels of ability, age, and motivation. The level of ability can be observed through the results of fundamental movement skills where the girl is slightly better than boys. In motivation, it seems that girls are very enthusiastic about participating in learning. In addition, the content of teaching materials can also affect the level of physical activity. Previous studies have reported that invasion games produce high-level activities such as soccer, basketball, and hockey [34].

Fundamental movement skills are in the category of below average. This can explain why the level of physical activity in locomotor physical education learning is also low. By mastering low fundamental movement skills, it is possible for children to have difficulty in learning motion and to be motivated in learning. The correlation between fundamental movement skills and the level of physical activity shows the importance of children in mastering fundamental movement skills. Mastery of fundamental movement skills positively contributes to the involvement 
of regular physical activity $[35,36]$ and the involvement of games and mastery of movement pattern in games [37]. Besides that, it also has an impact on involvement in sports activities in adulthood to gain health benefits by an active lifestyle [25].

\section{Conclusion}

The level of physical activity in physical education learning with locomotor teaching material content did not reach the recommended level of physical activity. Fundamental movement skills of the sample are in the below average category. There is a correlation between fundamental movement skills and the level of physical activity. Physical education class needs to pay attention to the intensity of children's physical activities to get benefit from physical activities besides learning through movement.

\section{Acknowledgments}

We would like to deliver our gratitude to Lembaga Penelitian dan Pengabdian kepada Masyarakat (LPPM) UPI for funding the study. We would also deliver our sincere gratitude to all participants who had involved in the study.

\section{REFERENCES}

[1] Kemenkes. (2019). Rekomendasi aktifitas fisik bagi remaja [Internet]. Tersedia pada :http://p2ptm.kemkes.go.id/preview/infografhic/reko mendasi-aktivitas-fisik-bagi-remaja-di-luar-lingkungan-sek olah

[2] Penney, D., \& lisahunter. (2006). (Dis) Abling the (health and) physical in education: ability, curriculum and pedagogy. Sport, Education and Society, 11(3), 205-209.

[3] Sallis JF, McKenzie TL.(1991). Physical education's role in public health. Res Q Exerc Sport 1991;62:124-37.

[4] Costa, M., y López, E. (2000). Educación para la Salud. Una estrategia para cambiar los estilos de vida. Madrid: Ediciones Pirámide.

[5] Aznar, S., y Webster, T. (2006). Actividad Física y Salud en la Infancia y la Adolescencia. Madrid: Ministerio de Sanidad y Consumo. Ministerio de Educación y Ciencia. Disponible en:

[6] World Health Organization (2007). A guide for population-based aproaches to increasing levels of physical activity: implementation of the WHO Global Strategy on Diet, Physical Activity and Health. Documento: http://www.who.int/dietphysicalactivity/PA-promotiongui de-2007.pdf (Fecha de acceso: 3 de Abril de 2012).
[7] Strong, W.B., Malina, R. M., Blimkie, C. J. R., Daniels, S. R., Dishman, R. K., Gutin, B., Hergenroeder, A. C., Must, A., Nixon, P. A., Pivarnik, J. M., Rowland, T., Trost, S. y Trudeau, F. (2005). Evidence based physical activity for schoolaged jouth. The Journal of Pediatrics, 146, 732-737.

[8] Strand, B., \& Anderson, C. (1996). A comparison of two instructional formats on heart rate intensity, skill achievement and student attitude. Nebraska Journal for the Nebraska Association of Health, Physical Education and Recreation, 27(2), 21-24.

[9] Lacy, A. C., \& La Master, K. J. (1990). Analysis of fitness activities in junior high school physical education. Physical Educator, 47(3), 176.

[10] Strand, B. N., Scantling, E., \& Johnson, M. (1997). Fitness education: Teaching concepts-based fitness in the schools. Gorsuch Scarisbrick, Publishers.

[11] American College of Sports Medicine. (2000). ACSM's guidelines for exercise testing and prescription (6th ed.). Philadelphia: Lippincott, Williams, and Wilkins.

[12] Sallis, J.F., Patrick, K. (1994). Physical activity guidelines for adolescents: a consensus statement. Pediatric Exercise Science, 6, 302-314.

[13] Baquet, B., Berthoin, S., Van Praagh, E. (2002). Are intensified physical education sessions able to elicit heart rate at a sufficient level to promote aerobic fitness in adolescents? Research Quarterly for Exercise and Sport 73(3): 282-288

[14] Dudley D, Okely A, Pearson P and Cotton W (2011) A systematic review of the effectiveness of physical education and school sport interventions targeting physical activity, movement skills, and enjoyment of physical activity. European Physical Education Review 17: 353-378.

[15] Marques, A., Ferro, N., Diniz, J., Carreiro da Costa, F (2011). Health related fitness in physical education. 45 versus 90 minutes classes. British Journal of Sports Medicine 45: A11.

[16] Howe, C.A., Freedson, P.S., Alazán, S., Feldman, H.A, Osganian, S.K. (2012). A recess intervention to promote moderate-to-vigorous physical activity. Pediatric Obesity 7 , $82-88$.

[17] Stratton, G. (1996). Physical activity levels of 12-13 year old Schoolchildren during European handball lessons: Gender and ability group differences. European Physical Education Review, 2(2), 165-173. https://doi.org/10.1177/ 1356336X9600200208

[18] Laurson, K.R., Brown, D.D., Cullen, R.W., Dennis, K.K. (2008). Heart rates of High School Physical Education Students during team sports, individual sports and fitness activities. Research Quarterly for Exercise and Sport 79(1): 85-91

[19] Duncan, J.S., Badland, H.M., Schofield, G. (2009). Combining GPS with heart rate monitoring to measure physical activity in children: a feasibility study. Journal of Sports Science and Medicine, 12(5): 583-585.

[20] Luis, J., \& Lucas, Y. (2015). ORIGINAL INTENSITY OF PHYSICAL EDUCATION CLASSES IN ADOLESCENT S. (June). 
[21] Adams, J.B. (2009). High School Physical Education Students' Heart Rates during different activities. Journal of Physical Education, Recreation and Dance 80(9): 8.

[22] Gao, Z. Hanno, J.C., Carson, R.L. (2009). Middle schools students' heart rates during different curricular activities in physical education. International Council of Health, Physical Education, Recreation, Sport and Dance Journal of Research, 4(1): 16-19.

[23] Depdiknas, D. M., \& Direktorat, P. L. B. (2007). Pedoman umum penyelenggaraan pendidikan inklusif.

[24] Payne, G. \& Isaacs, L. (2011). Human motor development: a lifespan approach (8th Edition). Boston: Mac Graw Hill.

[25] Vandorpe, B. et al. 2012. "Relationship between Sports Participation and the Level of Motor Coordination in Childhood: A Longitudinal Approach." Journal of Science and Medicine in Sport 15(3): 220-25. Wibowo, R., Nugraha, E., \& Sultoni, K. (2018). Fundamental Movement Skills and Game Performance in Invasion Game Activities.

[26] Gabbard, C. (2011). Lifelong motor development (6th ed.). San Francisco, CA: Benjamin Cummings. Gallahue,

[27] Mitchell, B., McLennan, S., Latimer, K., Graham, D., Gilmore, J., \& Rush, E. (2013). Improvement of fundamental movement skills through support and mentorship of class room teachers. Obesity Research \& Clinical Practice, 7(3), e230-e234.

[28] Wibowo, R.; Nugraha, E. and Sultoni, K. (2018). Fundamental Movement Skills and Game Performance in Invasion Game Activities. In 2nd International Conference on Sports Science, Health and Physical Education - Volume 1: ICSSHPE, ISBN 978-989-758-317-9 ISSN 2184-2701, pages 390-395. DOI: 10.5220/0007061703900395

[29] Ulrich, D. A. (2000). Test of gross motor development: Examiner's manual (2nd ed.). Austin, TX: Pro-Ed.
[30] Barnett, L. M., Nicola D. R., Avigdor Z., Jo Salmon. 2015. "Face Validity and Reliability of a Pictorial Instrument for Assessing Fundamental Movement Skill Perceived Competence in Young Children.” Journal of Science and Medicine in Sport 18(1): 98-102.

[31] US Department of Health and Human Services (2010) Healthy People 2020 Objectives. Available at: http:// www.healthypeople.gov/2020/topicsobjectives2020/pdfs/ HP2020objectives.pdf (accessed 18 January 2011).

[32] Gehris, J., Myers, E., \& Whitaker, R. (2012). Physical activity levels during adventure-physical education lessons. European Physical Education Review, 18(2), 245-257. https://doi.org/10.1177/1356336X12440365

[33] McKenzie TL, Catellier DJ, Conway T, Lytle LA, Grieser M, Webber LA, et al. (2006) Girls' activity levels and lesson contexts in middle school PE: TAAG baseline. Medicine and Science in Sports and Exercise 38: 1229 1235.

[34] Simons-Morton, B.G., Taylor, W., Snider, S., \& Huang, I. (1993). The physical activity of fifth-grade students during physical education classes. American Journal of Public Health, 83, 262-264. *Simons-Morton,

[35] Iivonen, K S et al. 2013. "Relationship between Fundamental Motor Skills and Physical Activity in 4Year-Old Preschool Children 1, 2, 3." 627-46

[36] Barela, J. A. 2013. "Fundamental Motor Skill Proficiency Is Necessary for Children's Motor Activity Inclusion."Motriz. Revista de Educacao Fisica 19(3): 548-51.

[37] Fadilah, M., \& Wibowo, R. (2018). Kontribusi Keterampilan Gerak Fundamental Terhadap Keterampilan Bermain Small-Sided Handball Games. Jurnal Pendidikan Jasmani dan Olahraga, 3(1), 60-68. 